\title{
A prospective observational study on perioperative use of antibacterial agents in implant surgery
}

\author{
Marzena Dominiakk ${ }^{1, A, C-F}$, Stanislava Shuleva ${ }^{2, A-F}$, Spiridon Silvestros ${ }^{3, A, C-F}$, Gil Alcoforado $0^{4, A, C-F}$ \\ ${ }^{1}$ Department of Oral Surgery, Wroclaw Medical University, Poland \\ 2 Private practice, Sofia, Bulgaria \\ ${ }^{3}$ Department of Prosthodontics, Dental School National and Kapodistrian University of Athens, Greece \\ ${ }^{4}$ Private practice, Lisbon, Portugal \\ A - research concept and design; B - collection and/or assembly of data; C - data analysis and interpretation; \\ $D$ - writing the article; $E$ - critical revision of the article; $F$ - final approval of the article
}

\section{Address for correspondence \\ Marzena Dominiak}

E-mail:marzena.dominiak@wp.pl

\section{Funding sources}

This study was initiated and funded by Pierre Fabre Médicament, Paris, France.

\section{Conflict of interest}

Marzena Dominiak reports having received consulting fees from Pierre Fabre Pharmaceutical Laboratories.

Stanislava Shuleva reports having received consulting fees from Pierre Fabre Pharmaceutical Laboratories.

Spyridon Silvestros reports having received consulting fees from Pierre Fabre Pharmaceutical Laboratories.

Gil Alcoforado reports having received consulting fees from

Pierre Fabre Pharmaceutical Laboratories.

\section{Acknowledgements}

The authors would like to thank all the dental surgeons who participated in this study for their contribution, as well as Adam Doble (Foxymed, Paris) for medical writing support in the preparation of this article.

\section{Received on June 5, 2018}

Reviewed on October 27, 2018

Accepted on December 5, 2019

Published online on March 26, 2020

Cite as

Dominiak M, Shuleva S, Silvestros S, Alcoforado G. A prospective observational study on perioperative use of antibacterial agents in implant surgery. Adv Clin Exp Med. 2020;29(3):355-363. doi:10.17219/acem/115087

DOI

10.17219/acem/115087

\section{Copyright}

Copyright by Author(s)

This is an article distributed under the terms of the

Creative Commons Attribution 3.0 Unported (CC BY 3.0)

(https://creativecommons.org/licenses/by/3.0/)

\begin{abstract}
Background. Dental implant surgery has become routine practice for replacing missing teeth. Little is known about the use of local antisepsis to control the development of bacterial plaque and to facilitate healing, as current practice guidelines do not address this issue.

Objectives. The objectives of this study were to describe antiseptic practices for implant surgery and to assess plaque control at the operative site as well as the investigator's satisfaction.

Material and methods. This prospective, observational study conducted in 4 European countries enrolled 911 adult patients receiving a single or multiple implant on the day of inclusion. Any medication prescribed during the pre- or postoperative periods was documented, particularly antibiotics, antiseptic mouthwashes and topical antiseptic gels. At a follow-up visit, the presence of plaque was documented on teeth adjacent to the implant and its extent determined using the Silness-Löe index.
\end{abstract}

Results. Oral antibiotics were prescribed prior to surgery in $53.8 \%$ of the patients. Antiseptic mouthwashes were prescribed to patients (49.6-65.7\%) according to country. Following dental implant placement, 84.1-94.7\% of patients were prescribed oral antibiotics, $45.6-86.5 \%$ of patients were prescribed antiseptic mouthwash and $72.8-100 \%$ of patients were prescribed an antiseptic gel. At the follow-up visit, plaque was observed in $45.4 \%$ of the patients. The mean Silness-Löe plaque index was 0.7 or 0.8 , indicating a low level of plaque accumulation. The Löe and Silness gingival index was 0.6 or 0.7 , which is consistent with a low level of gingival inflammation.

Conclusions. Use of antibiotics pre- and post-surgery is frequent in implant surgery, despite it being discouraged in practice guidelines. Use of antiseptic mouthwashes and topical antiseptic gels is widespread, although treatment paradigms vary widely. Practice guidelines covering antisepsis provision would be useful, since those products could be used as an alternative to antibiotics to facilitate wound healing.

Key words: dental implants, chlorhexidine, antibacterial agents, antiseptic gel, mouthwash 


\section{Introduction}

Dental implant surgery has become routine practice for replacing missing teeth. ${ }^{1,2}$ In 1988 , it was estimated that 100,000-300,000 dental implants were placed every year worldwide, ${ }^{3}$ whereas more recent data indicates that 3,000,000 people in the USA alone now have dental implants and that this number is growing by 500,000 per year. ${ }^{4}$

Over the last 30 years, considerable evidence has accumulated demonstrating the long-term stability of dental implants, with long-term success rates $>95 \%$ after 5 years $^{5,6}$ and $>90 \%$ after 15 years. ${ }^{7}$ However, long-term survival of the implants may be compromised by inflammatory damage of the surrounding peri-implant tissues, leading to bone loss and subsequent implant loss. ${ }^{8}$ This is a consequence of peri-implant mucositis, characterized by inflammation of the mucosa surrounding the implant, or of peri-implantitis, where both the mucosa and the underlying bone are affected. ${ }^{8}$ Peri-implant mucositis may affect $80 \%$ of the subjects with dental implants and $50 \%$ of the implants, and peri-implantitis up to $56 \%$ of subjects and up to $40 \%$ of the implants. ${ }^{8,9}$

Both abovementioned peri-implant diseases are caused by accumulation of bacteria from dental biofilms. As with natural teeth, there is a direct relationship between plaque accumulation and peri-implant disease. For this reason, good oral hygiene and maintenance strategies are critical for the long-term success of dental implant placement. Although international ${ }^{10-13}$ and national ${ }^{7,14-16}$ guidelines on different aspects of dental implant surgery have been published, none of these have specifically focused on perior postoperative local antiseptic management aimed at preventing plaque accumulation. In particular, there is no guidance for practitioners on the optimal timing and type of local antiseptic therapy to provide for their patients.

Local antiseptic therapy, using a mouthwash or a gel form containing an active antiseptic agent such as chlorhexidine, is widely accepted in oral surgery to prevent plaque formation and consequently to facilitate wound healing. The purpose of this local antisepsis is firstly to control the development of bacterial plaque in the direct environment of the operative wound, such as on the sutures in soft tissues, on healing screws (used in one-stage treatment procedures) and on adjacent teeth, and secondly to facilitate the physiological healing process by preventing potential delays due to localized inflammatory phenomena. Antiseptic gels may be of particular interest as they are applied directly in situ to the site of the operative wound, where they may provide a barrier effect, and present a longer-lasting antiseptic action compared to a mouthwash. This may provide a perceived benefit to patients who may be reluctant to interfere with the wound site during the postoperative period due to pain and fear of "weakening" the implant. In preclinical models, it has been demonstrated that application of a chlorhexidine-based gel may speed up the rate of healing of an intrabuccal surgical wound in experimental animals. ${ }^{17}$

The lack of explicit consensus practice guidelines for perioperative (especially postoperative but also preoperative) antiseptic management in dental implant surgery has resulted in a range of individualized practices, whose use and outcomes are very insufficiently documented. In addition, disparities in national and even regional practice may exist, especially due to the workings of various healthcare systems. It is thus important to collect information on the use of local antiseptic product in routine clinical practice.

The objectives of this study, conducted in 4 European countries, were to describe antiseptic practices for implant surgery and to assess plaque control at the operative site as well as the investigator's satisfaction. Recommendations for dental care provided by the practitioner after surgery were also evaluated.

\section{Material and methods}

This prospective, longitudinal, observational study was conducted in 4 European countries; Poland, Bulgaria, Portugal, and Greece. The investigator sites were dental surgeons' offices specialized or with a special interest in implantology and with regular implant activity of at least 1 implant per week. The study was performed between October 2015 and January 2016.

\section{Participating centers}

Dental surgeons were selected from the national register and stratified by region. Potential sites were randomly selected from each region based on the total number of surgeons in the region. To minimize selection bias, each dental practice was contacted sequentially in the order of the list and invited to participate in the study. Any reasons for refusal were recorded. This process continued until the required number of sites was obtained.

\section{Patients}

Adult patients (aged 18 years or older) for whom implant surgery had been indicated by the investigator and who received on the day of inclusion a single or multiple implant for which the surgical site was bordered by at least 1 tooth were eligible to be enrolled in the study. Patients were enrolled on the day they presented for the procedure. The dentist was free to decide if a one- or two-stage procedure and either a single or multiple implant therapy was appropriate and all surgical conditions were accepted. Participants were required to have healthy periodontal tissue or stabilized periodontal disease and patient management was expected to include at least 1 intra-oral antiseptic in the postoperative phase. Participants were excluded 
if they were already enrolled in a clinical trial or were totally edentulous. All patients were required to provide informed consent.

\section{Procedures and follow-up}

In line with the observational nature of the study, no study-specific interventions were required. Patients were included in the study on the day on which dental implant placement was performed. Each investigator was encouraged to follow their normal routine. Participants received no additional incentives to adhere to the recommendations other than those which the investigator employed in their normal routine. The participant returned after a period of 7-21 days for a follow-up visit to assess the sutures and wound healing, according to routine practice. The time until the follow-up visit was decided by the investigator on a case-by-case basis. Participating sites were monitored throughout the study in order to optimize the quality of the data collected.

\section{Data collection}

Data was collected at the inclusion visit on the day of the procedure and on the day of the follow-up visit. At the inclusion visit, the dentist documented the patient's general health and periodontal disease, as well as the type of surgery performed. Any medication prescribed during the preoperative or postoperative periods was documented, and in particular, systemic and local antibacterial treatment - antibiotics and antiseptics (mouthwashes, gels). Other prescribed medications (non-steroidal antiinflammatory drugs (NSAIDs), oral corticosteroids, oral analgesics, topical analgesics, and scar-healing products) have been also documented (data not shown). Any specific postoperative recommendations or counseling provided were also recorded.

At the follow-up visit, the presence of plaque was documented on teeth adjacent to the implant and its extent determined by the Silness-Loë plaque index. ${ }^{18}$ This index measures the accumulation of plaque on 4 surfaces of individual teeth on a four-point Likert scale ranging from 0 (no plaque) to 3 (abundance of soft matter within the gingival pocket and/or on the tooth and gingival margin). The tooth score is calculated as the mean of the individual scores for each of the 4 surfaces. A global score can be calculated as the mean values for several individual teeth. The state of the gums at the operative site (measured on the teeth adjacent to the implant site or on the provisional prosthesis) was scored using the Löe and Silness gingival index. ${ }^{19}$ This index measures gingival inflammation in proximity to individual teeth on a five-point Likert scale ranging from 0 (absence of inflammation) to 4 (severe inflammation defined by the presence of erythema, edema, marginal gingival hypertrophy of the unit or spontaneous bleeding, papillary, congestion, or ulceration). Individual tooth scores or global scores are calculated as for the plaque index. The dentist's satisfaction with the oral antiseptic gel used during the postoperative period was evaluated with respect to 5 items, each rated on a ten-point numerical rating scale ranging from 1 (very unsatisfied) to 10 (very satisfied). Any adverse events reported during the study were to be documented on the case report form.

\section{Sample size determination}

The targeted sample size for the study was determined a priori in order to estimate the key variables at an assumed frequency of $50 \%$ with an accuracy of $5 \%$. To achieve this, a total of 1,064 (266 per country) patients would be needed to be included. To achieve this, the target number of participating centers was 60 (15 per country), assuming that $70 \%$ of the centers would be active at the end of the inclusion period.

\section{Statistical analysis}

Analysis of the data was principally descriptive and no hypothesis was tested in the study. Categorical variables are reported as frequency counts and percentages, and continuous variables as mean values with standard deviation (SD) or median values with range. Missing data were not replaced. Data from each country were analyzed separately. The statistical analysis was carried out using $\mathrm{SAS}^{\circledR}$ v. 9.4 software (SAS Institute, Cary, USA).

\section{Ethics}

The study was conducted in accordance with the Guidelines of Good Practice in Epidemiology and pertinent international and national legislation. Approval was received from the national ethics committees in Greece, Poland and Portugal. In Bulgaria, ethics committee approval was waived since the study did not influence patient care. Written informed consent was obtained from all patients and no nominative information was recorded in the study database.

\section{Results}

Overall, 911 subjects receiving a dental implant were recruited into the study: 257 in Poland, 275 in Bulgaria, 207 in Greece, and 172 in Portugal. Two subjects in Portugal who were under 18 years of age were excluded from the analysis. The remaining 909 subjects were eligible for analysis. The demographic characteristics of these subjects are presented in Table 1 . These were essentially similar between countries, with a mean age of around 50 years and a slight preponderance of women.

Clinical characteristics are presented in Table 2. Patients were comparable between countries, although Greek par- 
Table 1. Socio-demographic characteristics of the subjects enrolled

\begin{tabular}{|c|c|c|c|c|}
\hline Variable & $\begin{array}{l}\text { Poland } \\
n=257\end{array}$ & $\begin{array}{c}\text { Bulgaria } \\
n=275\end{array}$ & $\begin{array}{l}\text { Greece } \\
n=207\end{array}$ & $\begin{array}{c}\text { Portugal } \\
n=170\end{array}$ \\
\hline $\begin{array}{l}\text { Gender } \\
\text { men } \\
\text { women }\end{array}$ & $\begin{array}{c}n=247 \\
109(44.1 \%) \\
138(55.9 \%)\end{array}$ & $\begin{array}{c}n=271 \\
134(49.4 \%) \\
137(50.6 \%)\end{array}$ & $\begin{array}{c}n=202 \\
85(42.1 \%) \\
117(57.9 \%)\end{array}$ & $\begin{array}{c}n=166 \\
75(45.2 \%) \\
91(54.8 \%)\end{array}$ \\
\hline Age, mean \pm SD [years] & $\begin{array}{c}n=251 \\
48.0 \pm 12.2\end{array}$ & $\begin{array}{c}n=274 \\
47.0 \pm 13.2\end{array}$ & $\begin{array}{c}n=204 \\
52.6 \pm 13.2\end{array}$ & $\begin{array}{c}n=166 \\
51.2 \pm 14.1\end{array}$ \\
\hline $\mathrm{BMI}$, mean $\pm \mathrm{SD}\left[\mathrm{kg} / \mathrm{m}^{2}\right]$ & $\begin{array}{c}n=253 \\
24.3 \pm 3.7\end{array}$ & $\begin{array}{c}n=274 \\
24.9 \pm 4.0\end{array}$ & $\begin{array}{c}n=203 \\
25.6 \pm 4.3\end{array}$ & $\begin{array}{c}n=156 \\
24.4 \pm 3.3\end{array}$ \\
\hline
\end{tabular}

SD - standard deviation; BMI - body mass index.

Table 2. Clinical characteristics of the subjects enrolled

\begin{tabular}{|c|c|c|c|c|}
\hline Variable & $\begin{array}{l}\text { Poland } \\
n=257\end{array}$ & $\begin{array}{l}\text { Bulgaria } \\
n=275\end{array}$ & $\begin{array}{l}\text { Greece } \\
n=207\end{array}$ & $\begin{array}{l}\text { Portugal } \\
n=170\end{array}$ \\
\hline Periodontal disease history & $\begin{array}{c}n=251 \\
46(18.3 \%)\end{array}$ & $\begin{array}{c}n=261 \\
71(27.2 \%)\end{array}$ & $\begin{array}{c}n=193 \\
84(43.5 \%)\end{array}$ & $\begin{array}{c}n=166 \\
22(13.3 \%)\end{array}$ \\
\hline $\begin{array}{l}\text { Type of periodontal disease } \\
\text { chronic periodontitis } \\
\text { aggressive periodontitis } \\
\text { other type of periodontitis }\end{array}$ & $\begin{array}{c}n=42 \\
34(81.0 \%) \\
1(2.4 \%) \\
7(16.7 \%)\end{array}$ & $\begin{array}{c}n=70 \\
65(92.9 \%) \\
4(5.7 \%) \\
1(1.4 \%)\end{array}$ & $\begin{array}{c}n=78 \\
65(83.3 \%) \\
9(11.5 \%) \\
4(5.1 \%)\end{array}$ & $\begin{array}{c}n=21 \\
16(76.2 \%) \\
1(4.8 \%) \\
4(19.0 \%)\end{array}$ \\
\hline $\begin{array}{l}\text { Oral hygiene: presence of plaque } \\
\text { very good (no plaque) } \\
\text { average ( }<30 \% \text { of teeth with plaque) } \\
\text { poor ( }>30 \% \text { of teeth with plaque) }\end{array}$ & $\begin{array}{c}n=249 \\
128(51.4 \%) \\
119(47.8 \%) \\
2(0.8 \%)\end{array}$ & $\begin{array}{c}n=269 \\
152(56.5 \%) \\
113(42.0 \%) \\
4(1.5 \%)\end{array}$ & $\begin{array}{c}n=206 \\
67(32.5 \%) \\
125(60.7 \%) \\
14(6.8 \%)\end{array}$ & $\begin{array}{c}n=163 \\
65(39.9 \%) \\
92(56.4 \%) \\
6(3.7 \%)\end{array}$ \\
\hline $\begin{array}{l}\text { Comorbidities } \\
\text { diabetes mellitus } \\
\text { heart disease } \\
\text { other comorbidity }\end{array}$ & $\begin{array}{c}n=257 \\
8(3.1 \%) \\
10(3.9 \%) \\
25(9.7 \%)\end{array}$ & $\begin{array}{c}n=275 \\
4(1.5 \%) \\
9(3.3 \%) \\
30(10.9 \%)\end{array}$ & $\begin{array}{l}n=207 \\
8(3.9 \%) \\
9(4.3 \%) \\
3(1.4 \%)\end{array}$ & $\begin{array}{l}n=170 \\
4(2.4 \%) \\
3(1.8 \%) \\
3(1.8 \%)\end{array}$ \\
\hline $\begin{array}{l}\text { Tobacco use } \\
\text { current smoker }\end{array}$ & $\begin{array}{c}n=252 \\
36(14.3 \%)\end{array}$ & $\begin{array}{c}n=271 \\
65(24.0 \%)\end{array}$ & $\begin{array}{c}n=206 \\
54(26.2 \%)\end{array}$ & $\begin{array}{c}n=162 \\
19(11.7 \%)\end{array}$ \\
\hline
\end{tabular}

Table 3. Characteristics of implant surgery performed

\begin{tabular}{|c|c|c|c|c|}
\hline Variable & $\begin{array}{l}\text { Poland } \\
n=257\end{array}$ & $\begin{array}{c}\text { Bulgaria } \\
n=275\end{array}$ & $\begin{array}{l}\text { Greece } \\
n=207\end{array}$ & $\begin{array}{c}\text { Portugal } \\
n=170\end{array}$ \\
\hline $\begin{array}{l}\text { Procedures } \\
\text { one-stage surgery } \\
\text { two-stage surgery } \\
\text { one-stage surgery and two-stage surgery }\end{array}$ & $\begin{array}{c}n=257 \\
58(22.8 \%) \\
195(76.8 \%) \\
1(0.4 \%)\end{array}$ & $\begin{array}{c}n=275 \\
104(38.2 \%) \\
168(61.8 \%) \\
-\end{array}$ & $\begin{array}{c}n=207 \\
49(23.8 \%) \\
155(75.2 \%) \\
2(1.0 \%)\end{array}$ & $\begin{array}{c}n=167 \\
102(61.1 \%) \\
63(37.7 \%) \\
2(1.2 \%)\end{array}$ \\
\hline Immediate temporization (one-stage surgery) & $\begin{array}{c}n=59 \\
3(5.1 \%)\end{array}$ & $\begin{array}{c}n=104 \\
33(31.7 \%)\end{array}$ & $\begin{array}{c}n=51 \\
4(7.8 \%)\end{array}$ & $\begin{array}{c}n=104 \\
20(19.2 \%)\end{array}$ \\
\hline $\begin{array}{l}\text { Implant placement } \\
\text { single } \\
\text { multiple }\end{array}$ & $\begin{array}{c}n=254 \\
152(59.8 \%) \\
102(40.2 \%)\end{array}$ & $\begin{array}{c}n=275 \\
156(56.7 \%) \\
119(43.3 \%)\end{array}$ & $\begin{array}{c}n=207 \\
99(47.8 \%) \\
108(52.2 \%)\end{array}$ & $\begin{array}{c}n=170 \\
111(65.3 \%) \\
59(34.7 \%)\end{array}$ \\
\hline
\end{tabular}

ticipants tended to have a higher frequency of periodontal disease and poorer dental hygiene. Comorbidities were documented in less than $10 \%$ of subjects and smoking rates were lower than national averages.

Implant surgery was performed in 2 stages for $64.1 \%$ of patients, with the exception of patients in Portugal, where one-stage surgery was more frequently performed (Table 3). In the case of one-stage surgery, immediate temporization was only performed in a minority of patients ( $<10 \%$ in Poland and Greece). Multiple sites were implanted in the same procedure for $42.8 \%$ of patients.

\section{Preoperative prescription}

Around 3/4 of patients (2/3 in Bulgaria) were prescribed an antibiotic or an antiseptic mouthwash, and most frequently both. Oral antibiotics were prescribed prior to surgery in $53.8 \%$ of patients, ranging from $48.0 \%$ in Poland to $58.6 \%$ in Bulgaria (Fig. 1). The most frequently prescribed class of antibiotics were beta-lactams (Table 4). Combinations of more than 1 antibiotic were prescribed to $38.8 \%$ of patients in Bulgaria, whereas this practice was uncommon ( $<5 \%$ of patients) in other countries (Table 4$)$. 
Table 4. Treatments used prior to dental implant placement

\begin{tabular}{|c|c|c|c|c|}
\hline Variable & $\begin{array}{l}\text { Poland } \\
\mathrm{n}=257\end{array}$ & $\begin{array}{l}\text { Bulgaria } \\
\mathrm{n}=275\end{array}$ & $\begin{array}{l}\text { Greece } \\
\mathrm{n}=207\end{array}$ & $\begin{array}{l}\text { Portugal } \\
n=170\end{array}$ \\
\hline $\begin{array}{l}\text { Treatment } \\
\text { neither antibiotic nor antiseptic mouthwash } \\
\text { antibiotic only } \\
\text { antiseptic mouthwash only } \\
\text { both antibiotic and antiseptic mouthwash }\end{array}$ & $\begin{array}{l}n=252 \\
69(27.4 \%) \\
22(8.7 \%) \\
65(25.8 \%) \\
96(38.1 \%)\end{array}$ & $\begin{array}{c}n=274 \\
94(34.3 \%) \\
46(16.8 \%) \\
20(7.3 \%) \\
114(41.6 \%)\end{array}$ & $\begin{array}{l}n=205 \\
51(24.9 \%) \\
46(22.4 \%) \\
43(21.0 \%) \\
65(31.7 \%)\end{array}$ & $\begin{array}{l}n=164 \\
43(25.9 \%) \\
42(25.3 \%) \\
34(20.5 \%) \\
47(28.3 \%)\end{array}$ \\
\hline $\begin{array}{l}\text { Oral antibiotic } \\
\text { beta-lactam } \\
\text { macrolide } \\
\text { combination therapy }\end{array}$ & $\begin{array}{c}n=118 \\
60(50.8 \%) \\
11(9.3 \%) \\
3(2.5 \%)\end{array}$ & $\begin{array}{c}n=160 \\
57(35.6 \%) \\
11(6.9 \%) \\
62(38.8 \%)\end{array}$ & $\begin{array}{c}n=111 \\
94(84.7 \%) \\
2(1.8 \%) \\
5(4.5 \%)\end{array}$ & $\begin{array}{c}n=89 \\
76(85.4 \%) \\
6(6.7 \%) \\
2(2.2 \%)\end{array}$ \\
\hline $\begin{array}{l}\text { Protocol } \\
\text { once only prior to procedure } \\
\text { other }\end{array}$ & $\begin{array}{c}n=97 \\
23(23.7 \%) \\
74(76.3 \%)\end{array}$ & $\begin{array}{c}n=153 \\
72(47.1 \%) \\
81(52.9 \%)\end{array}$ & $\begin{array}{c}n=104 \\
79(76.0 \%) \\
25(24.0 \%)\end{array}$ & $\begin{array}{c}n=81 \\
23(28.3 \%) \\
58(71.7 \%)\end{array}$ \\
\hline $\begin{array}{l}\text { Antiseptic mouthwash: treatment duration } \\
\text { starting } 7 \text { days prior to surgery } \\
\text { starting } 24 \text { h prior to surgery } \\
\text { starting on the day of the procedure } \\
\text { other treatment duration }\end{array}$ & $\begin{array}{c}n=157 \\
29(18.5 \%) \\
12(7.6 \%) \\
112(71.3 \%) \\
4(2.6 \%)\end{array}$ & $\begin{array}{c}n=132 \\
103(78.0 \%) \\
13(9.9 \%) \\
14(10.6 \%) \\
2(1.5 \%)\end{array}$ & $\begin{array}{c}n=106 \\
21(19.8 \%) \\
50(47.2 \%) \\
35(33.0 \%) \\
0\end{array}$ & $\begin{array}{c}n=79 \\
4(5.1 \%) \\
17(21.5 \%) \\
55(69.6 \%) \\
3(3.8 \%)\end{array}$ \\
\hline $\begin{array}{l}\text { Antiseptic mouthwash: treatment frequency } \\
\text { number of times per day (mean } \pm S D)\end{array}$ & $\begin{array}{l}n=32 \\
2.6 \pm 0.5\end{array}$ & $\begin{array}{l}n=107 \\
2.2 \pm 0.8\end{array}$ & $\begin{array}{l}n=36 \\
2.6 \pm 0.5\end{array}$ & $\begin{array}{l}n=19 \\
2.5 \pm 0.5\end{array}$ \\
\hline
\end{tabular}

SD - standard deviation.

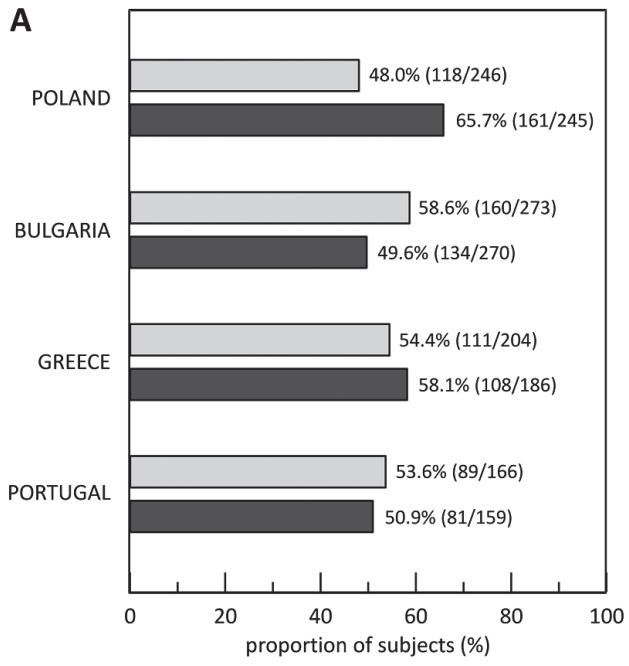

Greece was the only country where were the majority of patients were instructed to take the antibiotic only once prior to the procedure (Table 4). Antiseptic mouthwashes were prescribed in all countries, the frequency of use ranging from $49.6 \%$ of patients in Bulgaria to $65.7 \%$ in Poland (Fig. 1). In Poland and Portugal, the mouthwash was most frequently started on the day of the procedure, whereas in Bulgaria the majority of patients were prescribed an antiseptic mouthwash to be used for 7 days prior to the procedure (Table 4).

\section{Postoperative prescription}

Over $90 \%$ of patients received either a systemic antibiotic or an antiseptic mouthwash or both (Table 5). Oral antibiotics were prescribed following dental implant placement to the majority of patients in all countries, ranging from $84.1 \%$ in Bulgaria to $94.7 \%$ in Greece (Fig. 1). Again, beta-lactams were the most frequently prescribed class of antibiotic (Table 5). A relatively high proportion of patients in Bulgaria (30.7\%) and, to a lesser extent, in Greece (20.4\%) were prescribed more than 1 antibiotic (Table 5). An antiseptic mouthwash was prescribed to around half of the patients, except in Poland, where $86.5 \%$ received such a product (Fig. 1). For all but 18 patients who were prescribed a mouthwash, the active antiseptic ingredient was chlorhexidine. A topical antiseptic gel containing chlorhexidine was prescribed to nearly all patients, except in Greece, where this was the case for $72.8 \%$ of patients (Fig. 1). The gel was generally to be applied 2 or 3 times a day, and using a finger. In up to $40.4 \%$ of patients (in Portugal), a brush was used to apply the gel (Table 5). The duration of treatment was generally around 10 days. Use of an antiseptic gel did not differ according 
Table 5. Treatments prescribed for the postoperative period

\begin{tabular}{|c|c|c|c|c|}
\hline Variable & $\begin{array}{l}\text { Poland } \\
n=257\end{array}$ & $\begin{array}{l}\text { Bulgaria } \\
n=275\end{array}$ & $\begin{array}{l}\text { Greece } \\
n=207\end{array}$ & $\begin{array}{l}\text { Portugal } \\
n=170\end{array}$ \\
\hline $\begin{array}{l}\text { Treatment } \\
\text { neither antibiotic nor antiseptic mouthwash } \\
\text { antibiotic only } \\
\text { antiseptic mouthwash only } \\
\text { both antibiotic and antiseptic mouthwash }\end{array}$ & $\begin{array}{c}n=255 \\
15(5.8 \%) \\
22(8.6 \%) \\
10(3.9 \%) \\
208(81.6 \%)\end{array}$ & $\begin{array}{c}n=275 \\
25(9.1 \%) \\
112(40.7 \%) \\
22(8.0 \%) \\
116(42.2 \%)\end{array}$ & $\begin{array}{c}n=207 \\
4(1.9 \%) \\
97(46.9 \%) \\
7(3.4 \%) \\
99(47.8 \%)\end{array}$ & $\begin{array}{c}n=170 \\
7(4.1 \%) \\
91(53.5 \%) \\
8(4.7 \%) \\
64(37.7 \%)\end{array}$ \\
\hline $\begin{array}{l}\text { Oral antibiotic } \\
\text { beta-lactam } \\
\text { macrolide } \\
\text { combination therapy } \\
\text { other }\end{array}$ & $\begin{array}{c}n=230 \\
120(52.2 \%) \\
43(18.7 \%) \\
16(7.0 \%) \\
48(20.9 \%)\end{array}$ & $\begin{array}{c}n=228 \\
72(31.6 \%) \\
18(7.9 \%) \\
70(30.7 \%) \\
51(22.4 \%)\end{array}$ & $\begin{array}{c}n=196 \\
144(73.5 \%) \\
10(5.1 \%) \\
40(20.4 \%) \\
5(2.6 \%)\end{array}$ & $\begin{array}{l}n=155 \\
121(78.1 \%) \\
17(11.0 \%) \\
6(3.9 \%) \\
12(7.7 \%)\end{array}$ \\
\hline Chlorhexidine-based antiseptic gel & $\begin{array}{c}n=257 \\
238(92.6 \%)\end{array}$ & $\begin{array}{c}n=275 \\
270(98.2 \%)\end{array}$ & $\begin{array}{c}n=207 \\
150(72.5 \%)\end{array}$ & $\begin{array}{c}n=170 \\
169(99.4 \%)\end{array}$ \\
\hline Time after procedure initiated, mean \pm SD [h] & $\begin{array}{c}n=229 \\
11.4 \pm 13.2\end{array}$ & $\begin{array}{c}n=253 \\
8.8 \pm 10.5\end{array}$ & $\begin{array}{c}n=137 \\
12.1 \pm 7.3\end{array}$ & $\begin{array}{l}n=156 \\
4.6 \pm 6.0\end{array}$ \\
\hline $\begin{array}{l}\text { Number of applications per day } \\
1 \\
2 \\
3 \\
4 \text { or more }\end{array}$ & $\begin{array}{c}n=233 \\
13(5.6 \%) \\
106(45.5 \%) \\
105(45.1 \%) \\
9(3.9 \%)\end{array}$ & $\begin{array}{c}n=266 \\
4(1.5 \%) \\
88(33.1 \%) \\
56(21.1 \%) \\
118(44.4 \%)\end{array}$ & $\begin{array}{c}n=143 \\
0 \\
69(48.3 \%) \\
54(37.8 \%) \\
20(14.0 \%)\end{array}$ & $\begin{array}{c}n=164 \\
1(0.6 \%) \\
56(34.2 \%) \\
51(31.1 \%) \\
56(34.2 \%)\end{array}$ \\
\hline Duration of treatment, mean \pm SD [days] & $\begin{array}{c}n=200 \\
10.1 \pm 4.0\end{array}$ & $\begin{array}{c}n=234 \\
10.5 \pm 4.5\end{array}$ & $\begin{array}{c}n=100 \\
11.5 \pm 4.6\end{array}$ & $\begin{array}{c}n=141 \\
12.3 \pm 5.7\end{array}$ \\
\hline $\begin{array}{l}\text { Method of application } \\
\text { brush } \\
\text { finger } \\
\text { tongue } \\
\text { brush and finger }\end{array}$ & $\begin{array}{c}n=199 \\
36(18.1 \%) \\
160(80.4 \%) \\
0 \\
3(1.5 \%)\end{array}$ & $\begin{array}{c}n=237 \\
1(0.4 \%) \\
232(97.9 \%) \\
4(1.7 \%) \\
0\end{array}$ & $\begin{array}{c}n=121 \\
30(24.8 \%) \\
89(73.6 \%) \\
0 \\
2(1.7 \%)\end{array}$ & $\begin{array}{c}n=141 \\
31(22.0 \%) \\
84(59.6 \%) \\
0 \\
26(18.4 \%)\end{array}$ \\
\hline
\end{tabular}

SD - standard deviation.

to the characteristics of the patient or of the surgery undergone (data not shown).

In addition, recommendations on appropriate hygiene techniques were given to $80.2 \%$ of the patients and recommendations on cleaning the remaining teeth given to $80.5 \%$. Overall, $88.5 \%$ of patients were advised not to eat on the side of the operation and $87.8 \%$ to apply ice to relieve swelling. The pattern of these recommendations was similar between countries (Table 6), with the exception of Bulgaria, where patients were more frequently advised to refrain from smoking (76.7\% of patients) and less frequently advised to apply ice (63.1\%) than in the other 3 countries (Table 6).

\section{Clinical follow-up}

The clinical follow-up visit was made on average $9.7 \pm 6.5$ days after surgery, although this interval was highly variable (range: 0-97 days). The median interval was 8 days in all countries except Greece, where it was 7 days. At the follow-up visit, plaque was observed in $45.4 \%$ of patients, with

Table 6. Recommendations for postoperative care

\begin{tabular}{|c|c|c|c|c|}
\hline Variable & $\begin{array}{l}\text { Poland } \\
n=257\end{array}$ & $\begin{array}{l}\text { Bulgaria } \\
n=275\end{array}$ & $\begin{array}{l}\text { Greece } \\
n=207\end{array}$ & $\begin{array}{c}\text { Portugal } \\
n=170\end{array}$ \\
\hline Avoiding eating on the side of the wound & $\begin{array}{c}n=254 \\
223(87.8 \%)\end{array}$ & $\begin{array}{c}n=275 \\
245(89.1 \%)\end{array}$ & $\begin{array}{c}n=207 \\
174(84.1 \%)\end{array}$ & $\begin{array}{c}n=169 \\
159(94.1 \%)\end{array}$ \\
\hline Avoiding sucking on the side of the wound & $\begin{array}{c}n=254 \\
151(59.5 \%)\end{array}$ & $\begin{array}{c}n=275 \\
219(79.6 \%)\end{array}$ & $\begin{array}{c}n=207 \\
108(52.2 \%)\end{array}$ & $\begin{array}{c}n=169 \\
108(63.9 \%)\end{array}$ \\
\hline Recommendations on appropriate hygiene techniques & $\begin{array}{c}n=254 \\
196(77.2 \%)\end{array}$ & $\begin{array}{c}n=275 \\
238(86.6 \%)\end{array}$ & $\begin{array}{c}n=206 \\
151(73.3 \%)\end{array}$ & $\begin{array}{c}n=168 \\
139(82.7 \%)\end{array}$ \\
\hline Brushing the operated area with an appropriate material & $\begin{array}{c}n=255 \\
71(27.8 \%)\end{array}$ & $\begin{array}{c}n=275 \\
164(59.6 \%)\end{array}$ & $\begin{array}{c}n=206 \\
67(32.5 \%)\end{array}$ & $\begin{array}{c}n=168 \\
112(66.7 \%)\end{array}$ \\
\hline Recommendations for brushing the remaining teeth & $\begin{array}{c}n=253 \\
209(82.6 \%)\end{array}$ & $\begin{array}{c}n=274 \\
205(74.8 \%)\end{array}$ & $\begin{array}{c}n=207 \\
178(86.0 \%)\end{array}$ & $\begin{array}{c}n=170 \\
136(80.0 \%)\end{array}$ \\
\hline Not smoking & $\begin{array}{c}n=249 \\
87(34.9 \%)\end{array}$ & $\begin{array}{c}n=275 \\
211(76.7 \%)\end{array}$ & $\begin{array}{c}n=205 \\
52(25.4 \%)\end{array}$ & $\begin{array}{c}n=162 \\
89(54.9 \%)\end{array}$ \\
\hline Applying ice & $\begin{array}{c}n=254 \\
245(96.5 \%)\end{array}$ & $\begin{array}{c}n=255 \\
161(63.1 \%)\end{array}$ & $\begin{array}{c}n=207 \\
202(97.6 \%)\end{array}$ & $\begin{array}{c}n=170 \\
170(100 \%)\end{array}$ \\
\hline
\end{tabular}


Table 7. Clinical follow-up

\begin{tabular}{|c|c|c|c|c|}
\hline Variable & $\begin{array}{l}\text { Poland } \\
n=257\end{array}$ & $\begin{array}{l}\text { Bulgaria } \\
n=275\end{array}$ & $\begin{array}{l}\text { Greece } \\
n=207\end{array}$ & $\begin{array}{c}\text { Portugal } \\
n=170\end{array}$ \\
\hline Presence of visible plaque & $\begin{array}{c}n=234 \\
101(43.2 \%)\end{array}$ & $\begin{array}{c}n=253 \\
97(38.3 \%)\end{array}$ & $\begin{array}{c}n=182 \\
101(55.5 \%)\end{array}$ & $\begin{array}{c}n=151 \\
73(48.3 \%)\end{array}$ \\
\hline Mean plaque score on tooth/teeth adjacent to operating site & $\begin{array}{l}n=231 \\
0.7 \pm 0.7\end{array}$ & $\begin{array}{l}n=251 \\
0.8 \pm 0.7\end{array}$ & $\begin{array}{l}n=192 \\
0.8 \pm 0.7\end{array}$ & $\begin{array}{l}n=136 \\
0.8 \pm 0.7\end{array}$ \\
\hline \multicolumn{5}{|c|}{ Löe and Silness gingival index } \\
\hline Mean score on tooth/teeth adjacent to operating site & $\begin{array}{l}n=228 \\
0.7 \pm 0.6\end{array}$ & $\begin{array}{l}n=250 \\
0.6 \pm 0.6\end{array}$ & $\begin{array}{l}n=196 \\
0.7 \pm 0.7\end{array}$ & $\begin{array}{l}n=138 \\
0.7 \pm 0.6\end{array}$ \\
\hline Mean score on healing screws (for one-stage operations) & $\begin{array}{c}n=82 \\
0.6 \pm 0.6\end{array}$ & $\begin{array}{c}n=90 \\
0.7 \pm 0.7\end{array}$ & $\begin{array}{c}n=54 \\
0.8 \pm 0.6\end{array}$ & $\begin{array}{c}n=85 \\
0.4 \pm 0.6\end{array}$ \\
\hline
\end{tabular}

no major differences being observed between countries (Table 7). The mean Silness-Löe plaque index on teeth adjacent to the operating site was 0.7 or 0.8 in all 4 countries, indicating a low level of plaque accumulation (Table 7). The Löe and Silness gingival index was 0.6 or 0.7 according to country, both for teeth adjacent to the operating site and on the healing screws in the operating site (Table 7). This is consistent with a low level of gingival inflammation.

\section{Physician satisfaction}

In all countries, physicians expressed high levels of satisfaction with oral antiseptic gels for use in the postoperative period (Table 8). On all 5 items, mean satisfaction scores were $\geq 7.8$ on a scale ranging from 1 to 10 . Satisfaction levels were generally lowest in Portugal (range: 7.8-8.5 according to item) and highest in Bulgaria (8.5-9.5). With regard to individual items, the lowest scores were observed for plaque control (range: 7.8-8.5 according to country) and highest for suitability for postoperative management after implant surgery (8.5-9.5).

\section{Discussion}

This observational study performed in 4 European countries indicates that antiseptic therapy using mouthwashes and, in the postoperative period, topical antiseptic gels is a well-established part of the implant surgery protocol. Some differences were observed between countries in these practices, for example in the duration of treatment before surgery or in the extent of use in the postoperative period. Prior to surgery, around half of patients received oral antibiotics $(53.8 \%)$ and a similar proportion received an antiseptic mouthwash (56.3\%), although $28.7 \%$ received neither. These proportions were similar between countries. These 2 types of treatment were administered in the postoperative period. Around $90 \%$ of patients were prescribed an oral antibiotic in all countries, around 50\% were prescribed an antiseptic mouthwash, except in Poland, where this was the case for $86.5 \%$ of patients. Topical antiseptic gels were prescribed to $>90 \%$ of patients in all countries, except in Greece (72.8\%). A likely explanation of this practice in Greece is that clinicians prescribe antibiotic treatment post-surgically to $\sim 95 \%$ of patients (the highest percentage among the 4 countries) and, for this reason, local antiseptic gel is only prescribed adjunctively to the antibiotic. In Poland, due to the emphasis on reducing antibiotic therapy in generally healthy dental patients, local antisepsis with a mouthwash or gel is generally encouraged in pre-procedural and post-surgical protocols. In Portugal, clinicians are used to prescribe antibiotics in conjunction with implant surgery. Since bone grafts are very commonly used together with implant surgery, this could justify the need for antibiotics. The use of oral antiseptic rinses has been considered for many years to be

Table 8. Physician satisfaction with oral antiseptic gels for use in the postoperative period

\begin{tabular}{|c|c|c|c|c|}
\hline Variable & $\begin{array}{l}\text { Poland } \\
n=257\end{array}$ & $\begin{array}{c}\text { Bulgaria } \\
n=275\end{array}$ & $\begin{array}{l}\text { Greece } \\
n=207\end{array}$ & $\begin{array}{c}\text { Portugal } \\
n=170\end{array}$ \\
\hline Plaque control at the operating site(s) & $\begin{array}{l}n=256 \\
8.2 \pm 1.7\end{array}$ & $\begin{array}{l}n=268 \\
8.5 \pm 1.4\end{array}$ & $\begin{array}{l}n=202 \\
8.1 \pm 1.5\end{array}$ & $\begin{array}{l}n=164 \\
7.8 \pm 1.9\end{array}$ \\
\hline Inflammatory status at the operative site(s) & $\begin{array}{l}n=255 \\
8.1 \pm 1.6\end{array}$ & $\begin{array}{l}n=268 \\
8.9 \pm 1.5\end{array}$ & $\begin{array}{l}n=202 \\
8.2 \pm 1.5\end{array}$ & $\begin{array}{l}n=164 \\
8.2 \pm 2.8\end{array}$ \\
\hline Quality of wound healing of surgical site & $\begin{array}{l}n=255 \\
8.6 \pm 5.2\end{array}$ & $\begin{array}{l}n=268 \\
9.1 \pm 1.5\end{array}$ & $\begin{array}{l}n=202 \\
8.4 \pm 1.4\end{array}$ & $\begin{array}{l}n=163 \\
8.3 \pm 1.8\end{array}$ \\
\hline Effectiveness for postoperative management & $\begin{array}{l}n=236 \\
8.4 \pm 1.5\end{array}$ & $\begin{array}{l}n=265 \\
9.3 \pm 1.4\end{array}$ & $\begin{array}{l}n=147 \\
8.7 \pm 1.1\end{array}$ & $\begin{array}{l}n=161 \\
8.4 \pm 1.5\end{array}$ \\
\hline Suitability for postoperative management & $\begin{array}{l}n=235 \\
8.6 \pm 1.5\end{array}$ & $\begin{array}{l}n=263 \\
9.5 \pm 1.3\end{array}$ & $\begin{array}{l}n=144 \\
8.7 \pm 1.1\end{array}$ & $\begin{array}{l}n=161 \\
8.5 \pm 1.5\end{array}$ \\
\hline
\end{tabular}


good practice in most of the postoperative care protocols. In spite of certain practice differences between countries, due to diversity in education, healthcare system organization and economic level, practice was in general similar and the outcome in terms of absence of plaque around the implantation site was also similar.

No apparent differences were observed in the extent of antiseptic use according to the type of surgery performed. Practitioners in all countries encouraged appropriate hygiene techniques to ensure that plaque did not build up at the operative area. Ice was recommended to reduce pain and inflammation and refraining from smoking was advised to encourage healing.

Scientific evidence for the benefits of antibiotic prophylaxis during implant placement is limited..$^{20}$ In the early era of dental implant placement, implant surgery was seen as posing a high risk of infection and, for this reason, prophylactic antibiotic treatment before surgery was proffered systematically as a precautionary measure. ${ }^{21}$ However, the evidence accumulated from randomized clinical trials of perioperative antibiotic use in dental implant surgery suggests that the benefits are marginal. ${ }^{21-24}$ Current evidence is insufficient to recommend or discourage the use of prophylactic systemic antibiotics to prevent complications and failures of dental implants. ${ }^{20}$ Nonetheless, given the problem of antibiotic resistance, it is now recommended that use of antibiotics prior to uncomplicated dental implant placement surgery be limited to patients who are at specific risk for infections, such as immunosuppressed patients, or possibly in patients at high risk of failure, such as those undergoing immediate post-extractive implant placement. ${ }^{21,23,25,26}$ The potential benefit needs to be assessed at the individual patient level and carefully weighed against the risk of adverse reactions, side effects and the emerging problems with antibiotic resistance. ${ }^{20,21}$ In the present study, around $50 \%$ of the patients received antibiotics prior to surgery and around $90 \%$ received them for the postoperative period. These proportions suggest that prescription of antibiotics in routine practice in all participating countries extended well beyond the population of patients expected to be at specific risk.

With respect to antiseptic use during the postoperative period, a topical gel was prescribed to virtually all patients and around half received an antiseptic mouthwash as well. All the gel products and most of the mouthwashes contained chlorhexidine. Considerable variation was observed within countries, and to a lesser extent between countries, in the recommendations given to patients on when to start using the antiseptic gel after surgery, on how many times a day the gel was to be applied and for how many days the treatment should be continued following surgery. It may be helpful for practitioners and for planning of health service provision to develop standard protocols for the use of topical antiseptic gels after dental implant surgery.

Whatever the antibacterial protocol used for this study, the outcome at the follow-up visit was satisfactory. Both the Silness-Loë plaque index and the Löe and Silness gingival index on the teeth adjacent to the implantation site were $<1$, indicating good gingival status. Since the follow-up visit occurred at most 3 weeks after surgery, this is a good result. In addition, participating physicians reported being very satisfied with the suitability and effectiveness of topical antiseptic gels for postoperative management following dental implant surgery.

This study has several strengths and limitations. The strengths include the large number of patients included and the use of an identical protocol in 4 countries with very different healthcare systems. The limitations include the fact that, since dentist participation in the study was voluntary, it was not possible to ensure that their practice is representative of all implant surgery in the country. Given the design of the study, caution should therefore be exercised in interpreting the results. In addition, no longterm follow-up data was collected which could provide information on the benefits of antibiotic or antiseptic treatment in the postoperative period on periodontal health or on the need for supportive periodontal therapy a year following surgery.

\section{Conclusions}

The use of antiseptic mouthwashes prior to dental implant surgery and use of topical antiseptic gels after surgery is widespread in the countries participating in the study. However, treatment paradigms vary widely and it would be helpful to develop practice guidelines covering antisepsis provision in this field. Use of antibiotics is still widespread, in spite of this being discouraged in current practice guidelines, and may not have been justified in certain patients. Where antibiotics are not justified, antiseptics could be used as an alternative to ensure satisfactory wound healing. Nevertheless, interventional studies should be conducted to support this hypothesis and to identify the most appropriate protocol of administration. Education programs for dental surgeons on the issue of antibiotic use in implant surgery would be useful.

\section{ORCID iDs}

Marzena Dominiak (D) https://orcid.org/0000-0001-8943-0549 Stanislava Shuleva (D) https://orcid.org/0000-0003-0921-7727 Spiridon Silvestros (D) https://orcid.org/0000-0001-9900-0358 Gil Alcoforado (D) https://orcid.org/0000-0002-1545-2267

\section{References}

1. Ramanauskaite A, Baseviciene N, Wang HL, Tozum TF. Effect of history of periodontitis on implant success: Meta-analysis and systematic review. Implant Dent. 2014;23(6):687-696.

2. Quirynen M, Herrera D, Teughels W, Sanz M. Implant therapy: 40 years of experience. Periodontol 2000. 2014;66(1):7-12.

3. Dunlap J. Implants: Implications for general dentists. Dent Econ. 1988; 78(10):101-102,104,106 passim.

4. American Academy of Implant Dentistry. Facts and figures on dental implants https://www.aaid.com/about/Press_Room/Dental_ Implants_FAQ.html 
5. Jung RE, Pjetursson BE, Glauser R, Zembic A, Zwahlen M, Lang NP. A systematic review of the 5 -year survival and complication rates of implant-supported single crowns. Clin Oral Implants Res. 2008; 19(2):119-130.

6. Pjetursson BE, Tan K, Lang NP, Bragger U, Egger M, Zwahlen M. A systematic review of the survival and complication rates of fixed partial dentures (FPDs) after an observation period of at least 5 years. Clin Oral Implants Res. 2004;15(6):625-642.

7. Association of Dental Implantology. A Dentist's Guide to Implantology. London, UK: ADI; 2012.

8. Zitzmann NU, Berglundh T. Definition and prevalence of peri-implant diseases. J Clin Periodontol. 2008;35(8 Suppl):286-291.

9. Figuero E, Graziani F, Sanz I, Herrera D, Sanz M. Management of periimplant mucositis and peri-implantitis. Periodontol 2000. 2014;66(1): 255-273.

10. Bornstein MM, Al-Nawas B, Kuchler U, Tahmaseb A. Consensus statements and recommended clinical procedures regarding contemporary surgical and radiographic techniques in implant dentistry. Int J Oral Maxillofac Implants. 2014;29(Suppl):78-82.

11. Heitz-Mayfield LJ, Needleman I, Salvi GE, Pjetursson BE. Consensus statements and clinical recommendations for prevention and management of biologic and technical implant complications. Int J Oral Maxillofac Implants. 2014;29(Suppl):346-350.

12. Ad Hoc Committee for the Development of Dental Implant Guidelines. Guidelines for the provision of dental implants. Int J Oral Maxillofac Implants. 2008;23(3):471-473.

13. Sanz M, Donos N, Alcoforado G, et al. Therapeutic concepts and methods for improving dental implant outcomes. Summary and consensus statements. The $4^{\text {th }}$ EAO Consensus Conference 2015. Clin Oral Implants Res. 2015;26(Suppl 11):202-206.

14. Academy of Osseointegration. 2010 Guidelines of the Academy of Osseointegration for the provision of dental implants and associated patient care. Int J Oral Maxillofac Implants. 2010;25(3):620-627.

15. van Waas MA, Denissen HW, de Koomen HA, et al. Dutch consensus on guidelines for superstructures on endosseous implants in the edentulous mandible. J Oral Implantol. 1991;17(4):390-392.
16. Santé HA. Conditions de réalisation des actes d'implantologie orale: Environnement technique. Rev Stomatol Chir Maxillo-faciale. 2008; 109(5):334-340.

17. Hammad HM, Hammad MM, Abdelhadi IN, Khalifeh MS. Effects of topically applied agents on intra-oral wound healing in a rat model: A clinical and histomorphometric study. Int J Dent Hyg. 2011;9(1):9-16.

18. Löe H, Silness J. Periodontal disease in pregnancy. I. Prevalence and severity. Acta Odontol Scand. 1963;21(6):533-551.

19. Rebelo MAB, De Queiroz AC. Gingival indices: State of art. In: Panagakos F, Davies R, eds. Gingival Diseases: Their Aetiology, Prevention and Treatment. London, UK: InTech; 2011:41-54.

20. Park J, Tennant M, Walsh LJ, Kruger E. Is there a consensus on antibiotic usage for dental implant placement in healthy patients? Aust Dent J. 2018;63(1):25-33.

21. Lund B, Hultin M, Tranaeus S, Naimi-Akbar A, Klinge B. Complex systematic review: Perioperative antibiotics in conjunction with dental implant placement. Clin Oral Implants Res. 2015;26(Suppl 11):1-14.

22. Esposito M, Grusovin MG, Coulthard P, Oliver R, Worthington HV. The efficacy of antibiotic prophylaxis at placement of dental implants: A Cochrane systematic review of randomised controlled clinical trials. Eur J Oral Implantol. 2008;9(Suppl 1(2)):95-103.

23. Ahmad N, Saad N. Effects of antibiotics on dental implants: A review. J Clin Med Res. 2012;4(1):1-6.

24. Lawler B, Sambrook PJ, Goss AN. Antibiotic prophylaxis for dentoalveolar surgery: Is it indicated? Aust Dent J. 2005;50(4 Suppl 2):S54-59.

25. Agence française de sécurité sanitaire des produits de santé. Prescription des antibiotiques en pratique buccodentaire. Med Mal Infect. 2012;42(5):193-202.

26. Esposito M, Grusovin MG, Polyzos IP, Felice P, Worthington HV. Timing of implant placement after tooth extraction: Immediate, immediate-delayed or delayed implants? A Cochrane systematic review. Eur J Oral Implantol. 2010;3(3):189-205. 